\title{
ENGLISH LEARNING STRATEGY AS FOREIGN LANGUAGE RELATING TO DEMOGRAPHIC FACTORS ON FIRST GRADE CADETS OF POLTEKBANG
}

\author{
Laila Rochmawati ${ }^{1}$, Aris Wijanarko², Fatmawati $^{3}$, Meita Maharani $\mathrm{S}^{4}$ \\ Politeknik Penerbangan Surabaya \\ Jl. Jemur Andayani I, No. 73 Surabaya 60236 \\ Email : lailaharun@gmail.com
}

\begin{abstract}
The determing of language learning strategies that are often used by cadets in the Surabaya aviation polytechnic and knowing the correlation between the age, gender, major and educational background of each cadet are the goals in this reseach. Chi-Square test and Pearson product moment correlations test was used in order to determine whether or not common effect of age, gender, major and educational background of each cadet displayed significant differences on Language Learning Stratrgy of students. The results stated that the most frequently-used strategies were metacognitive strategies. The least frequently-used ones were affective strategies. The results of Pearson product moment correlations revealed that gender were the only demografic factors that were significantly correlated with the learners' learning strategy. The relationship between learners' learning strategy and gender was found to be positively significant .002 ( $\mathrm{sig}<.005$ ), learning strategy use associated with gender were significantly correlated.

Key Words: affective, cognitive, compensation, memory,metacognitive, social learning strategies.
\end{abstract}

\section{INTRODUCTION}

Learning is a complex issue and there are many factors that affect this process. One of these is individual difference. Individual differences play an important role in students' learning performances (Riding \& Rayner, 1998), because individuals have different features and therefore learn in a different way. They have different learning features, learning experiences, strengths and weaknesses, interest, motivation, learning methods and techniques. As a result of these differences, individuals have different learning outcomes. Research (Babadogan, 2000; Felder \& Brent, 2005) conducted on learning has emphasized that learningis individual as fingerprints, and that every human can learn within the proper learning circumstances. This feature of learning can be brought about by focusing on the sense of learning rather than the sense of teaching, and arises out of the learning to learn concept (Chickering, 2006). In this sense, students are independent learners that are aware of how they can learn most effectively, can find a way for learning in every circumstance and can monitor their own learning process. Students need to take responsibility for their learning rather than being completely dependent on their teacher. They can determine their own learning objectives, plan their own learning, select materials, and determine and use proper learning strategies and styles (Pritchard, 2009). In this sense, focusing on students' learning processes requires paying attention to learning strategies and styles. Language teaching can work well if there is one sufficient knowledge of the characteristics and behavior of learners. In a learning process, there is always a learner well done and less successful learners. Using learning strategies while learning helps students to acquire code and recall information successfully (Gagne, 1974). Students that use these strategies know how to learn effectively, and how they can store, remember and use the knowledge they learn and how they can monitor their learning. According to research, learning strategy usage brings about success 
for students (Gagne, 1974; Riding \& Rayner, 1998), increases motivation (Pintrich \& Schunk, 2002) and self-efficacy (Tunca \& Alkin-Sahin, 2014), and are related with epistemological belief (Deryakulu, 2004). In brief, it is the key to effective learning. This matter caused by various factors; one of which is the way people learn who studied it. In this case, Naiman, et al. (1978: 1) states that "All forms of language teaching can be developed with good if we have enough knowledge about the learner and about the learning process itself "(translation and print thick by the researchers). Thus, knowledge of the traits learners will be able to assist in facilitating learning activities teaching so that learners can achieve maximum results. This research is one effort to understand and explain the learning strategy of adults learning language. In in relation to the development of language teaching, research can is seen as one of the attempts to identify- factors influencing the success of language teaching. Included in these factors is a learner strategy used by learners in the learning process. Have been much research is done in this field; for example Naiman, et al. (1978), Cohen (1990), Oxford (1990), Phillips (1991). English Learning Strategy Pudyanti (1995), Zaerofi (1996), Suryanto (1997).By specializing in adult learners, this study intended to identify traits and habits and strategies learning adult learners in the process of learning English as a foreign language. The results of this study are expected, among them, can be contribute to the development and development of theory about learning strategies in teaching English as a second language. By involving 96 respondents from first grade cadets of Surabaya aviation polytechnic D.III management transportation and aronautical communication, this study aims to describe the nature of strategy. In this case, learning strategies lead to skills communicative (cognitive), supporting the independence of learners (affective), and oriented to problem solving (psychomotor). Third, learning strategies involve multiple factors within (internal) and external factors. Internal factors come from within the learners English Learning Strategy such as intelligence, attitudes, motivations, and learning habits. Factor externals come from outside such as teacher's role, social background ecopomy, and learning facilities. Meanwhile, Naiman, et al. (1978: 3) suggests ten types learning strategies derived from Stem (1975): plan, active, empathic, formal, experimental, semantic, exercise, communicative, monitor, and appreciation. This grouping seems to cover a lot things that happen in teaching and learning process. However, as is stated by Stem itself, these types of strategies still are temporary and require confirmation and modification. For example, some of those strategy groups still seem overlapping. Some traits in the plan strategy resemble the nature of the monitor strategy. Similarl strategi formal and exercise strategies. Many researchers are classifying learning strategies to be 4 types: cognitive, metacognitive, affective, and social (Naiman, et al., 1978; O'Malley and Chamot, 1990; Cohen, 1990; Oxford, 1990). Strategy cognitive relates to the thinking power of the learner in the process teaching and learning materials. Metacognitive strategies are associated with tactics or ways of learning to deal with and manage materials learn how to teach. Affective strategies relate to attitudes and feelings of learners in facing the learning process of learners. Social strategies relate to learner cooperation with colleagues in achieving learning goals.

Various researchers have studied factors related to the choice of language learning strategies. These factors include: 1) motivation; 2) learning styles; 3) sex; 4) cultural background; 5) attitudes and beliefs; 6) type of task; and 7) age and stage L2. Oxford (1990a) synthesizes existing research on how these factors influence the choice of strategies used among students who learn a second language.

The lesson is related to the gender, age, educational background, and background of the learners' field of knowledge. The question research is formulated as follows: (1) what is the profile of adult learning strategy in the sixth? categories of learning strategies Memory, Cognitive, Compensation, Metacognitive, Affective, and Social ?; (2) what kind of gender 
influence, age, educational background, and background knowledge of the field of adult learners towards the use of the learning strategy?

\section{METHODOLOGY}

\section{Participants}

95 adult student respondents in second grade of Politecnic of Surabaya Air Mmanagement Transportation and Aeronautical communication, aging 16-42 participated in the study and filled with items in the demographic information section. Among the 96 students participating in the study, 24 were male and 48 were female. Instrument For the purposes of this study, the instrument used during this study is an Indonesian version of the 50-item Strategy of Supply for Language Learning (SILL) which is highly reliable and the most commonly used measure for assessing language learning strategies (Oxford, 1990). The Alpha Cronbach reliability index for this questionnaire was reported 0.88. SILL contains six sub categories; namely memory strategy, cognitive, compensation, metacognitive, affective and social.

\section{Instrumentations}

Strategy of Supply for Language Learning (SILL). The bahasa version of Oxford's Strategy Inventory for Language Learning (SILL, 1990) was the second instrument utilized in this study to assess participants' choice and frequency of strategy use. The questionnaire had already been piloted and validated in Iranian context by Pishghadam (2008). SILL consists of 50 items, including 6 categories of memory, cognitive, compensation, metacognitive, affective, and social strategies. The Cronbach's alpha reliability of SILL in the present study was found to be 0.92 , indicating a high reliability coefficient. As the third instrument, a semistructured interview was conducted. The interview guide comprised seven expert validated items.

Immediate Retrospective Interviews. The qualitative data in this study was what the test-takers had to say about their own strategy use. The interviews were carried out to gather extra information in relation to the research questions. For interview, the students were ranked in three different levels of listening proficiency based on their scores in the listening proficiency test, advanced, upper intermediate and intermediate levels. Eight participants were chosen from the subjects, four from the advanced.

\section{Procedure}

The Inventory Strategy for Language Learning (SILL) Questionnaire was piloted with 96 second-grade students participating in a general English course held at two programs in Surabaya's Polytechnic Flight. The researchers were present as students filled in the questionnaire, giving them the opportunity to ask questions that might come to mind. After this stage, the data entered into the Package Statistics for Social Sciences (SPSS), 2.0 th version. In order to collect information on strategy use, Oxford's (1990) 50-item Strategy Inventory for Language Learning (SILL, version 7.0) was adapted for the study. The SILL was developed by Rebecca Oxford (1990a) as an instrument for assessing the frequency of use of language learning strategies by students. It appears that SILL is the 'most often used strategy scale around the world', and the only language learning strategy instrument that has been checked for reliability and validated in multiple ways (Oxford \& Burry-Stock, 1995).

The 50 items in the SILL comprise 6 categories: Memory, Cognitive, Compensation, Metacognitive, Affective, and Social strategies. The SILL uses a 5-point Likert scale for which the learners are guided to respond to a strategy description such as 'I try not to translate word-for-word', and the criteria used for evaluating the degree of strategy use 
frequency are: low frequency use (1.0-2.49), moderate frequency use (2.5-3.49), and high frequency use (3.55.0). Data elicited from students' responses to each item in the SILL were analyzed using SPSS. The questionnaires were given out during students' regular English classes in the first grade semester, 2017. In this study the SILL questionnaire had an alpha reliability coefficient of 0.84 . The ANOVA test was used to determine significant variation in mean strategy use by gender, proficiency and self-efficacy. In addition, Tukey test was used to determine specific differences across all the six SILL categories by gender, proficiency and self-efficacy.

\section{RESULTS AND DISCUSSIONS}

Results.

First, the descriptive statistics were calculated, the result of which is summarized and tabulated in Table 1.

Table 1. Descriptive statistics of the learners' scores on SILL

\begin{tabular}{llrrrr}
\hline & & & \multicolumn{2}{c}{ Cumulative } \\
\hline \multirow{3}{*}{ Valid } & & Frequency & Percent & Valid Percent & Percent \\
\cline { 2 - 6 } & Memory & 4 & 4.2 & 4.2 & 4.2 \\
\cline { 2 - 6 } & Cognitive & 22 & 23.2 & 23.2 & 27.4 \\
\cline { 2 - 6 } & Metacognitive & 48 & 50.5 & 50.5 & 77.9 \\
\cline { 2 - 6 } & Affective & 3 & 3.2 & 3.2 & 81.1 \\
\cline { 2 - 6 } & Socio & 18 & 18.9 & 18.9 & 100.0 \\
\cline { 2 - 6 } & Total & 95 & 100.0 & 100.0 & \\
\hline
\end{tabular}

As can be seen in Table 1, the most frequently-used strategies were metacognitive strategies which has more than 50 percent the exactly was $50.5 \%$, the second sequence was cognitive which $23.2 \%$, the third was $18.9 \%$ for socio and the fourth $4.2 \%$ for memory. The least frequently-used ones were affective strategies which frequency was 3.2 percent. Next, the spesicly of participants' age, gender, course and background knowledge and learning strategy were calculated, which is presented in Table 2, 3, 4, and 5 below.

Table 2. Cross tabulation for the participants' learning strategy and gender

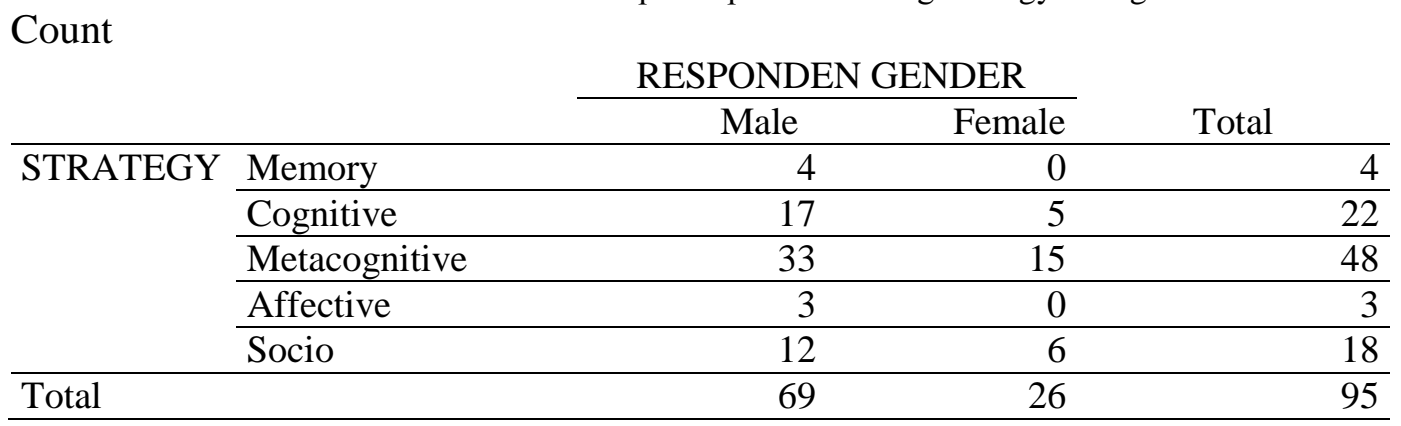

As Table 2 shows, based on the cross tabulation for the participants' learning strategy and gender, the learners' most prevalent learning strategy was metacognitive not only for the male but also for the female with the frequency level of 33 for male and 15 for female. The second place was cognitive for male and socio for frmale. The fourth sequence socio for male and female were socio. The fifth and sixth for male was memory and affective strategy. In the other hand there no body choose memory and affective strategy in the female side. 
Table 3. Crosstabulation for the participants' learning strategy and age

Count

\begin{tabular}{|c|c|c|c|c|c|c|c|}
\hline & \multicolumn{5}{|c|}{ AGE } & \multirow[b]{2}{*}{ Total } \\
\hline & & 17 & 18 & 19 & 20 & 21 & \\
\hline \multirow[t]{6}{*}{ STRATEGY } & Memory & 1 & 0 & 2 & 0 & 1 & 4 \\
\hline & Cognitive & 3 & 14 & 5 & 0 & 0 & 22 \\
\hline & Metacognitive & 5 & 19 & 18 & 5 & 1 & 48 \\
\hline & Affective & 0 & 1 & 2 & 0 & 0 & 3 \\
\hline & Socio & 0 & 13 & 2 & 3 & 0 & 18 \\
\hline & Total & 9 & 47 & 29 & 8 & 2 & 95 \\
\hline
\end{tabular}

Table three describe of participants' learning strategy and age. It can be seen that metacognitive strategy in the first place from all of the age. The second was cognitive and followed sosio, memory and affective.

Table 4. Cross tabulation for the participants' learning strategy and major

Count

\begin{tabular}{|c|c|c|c|c|c|c|}
\hline & \multicolumn{4}{|c|}{ RESPONDEN MAJOR/COURSE } & \multirow[b]{2}{*}{ Total } \\
\hline & & FSO 3A & FSO 3B & AMT 3A & AMT 3B & \\
\hline \multirow[t]{5}{*}{ STRATEGY } & Memory & 1 & 0 & 1 & 2 & 4 \\
\hline & Cognitive & 7 & 6 & 5 & 4 & 22 \\
\hline & Metacognitive & 11 & 12 & 13 & 12 & 48 \\
\hline & Affective & 1 & 1 & 1 & 0 & 3 \\
\hline & Socio & 4 & 4 & 4 & 6 & 18 \\
\hline Total & & 24 & 23 & 24 & 24 & 95 \\
\hline
\end{tabular}

Table 5. Cross tabulation for the participants' learning strategy and background knowledge Count

\begin{tabular}{llrrrrr}
\hline & & \multicolumn{3}{c}{ background knowledge } & \\
\cline { 2 - 6 } & & science & social & vocation & total \\
\hline \multirow{2}{*}{ strategy } & memory & 2 & 2 & 0 & 4 \\
\cline { 2 - 6 } & cognitive & 12 & 9 & 1 & 22 \\
\cline { 2 - 6 } & metacognitive & 21 & 26 & 1 & 48 \\
\cline { 2 - 6 } & affective & 2 & 1 & 0 & 3 \\
\cline { 2 - 6 } & Socio & 7 & 10 & 1 & 18 \\
\hline total & & 44 & 48 & 3 & 95 \\
\hline
\end{tabular}

Same with previous table, in table four, Cross tabulation for the participants' learning strategy and major. anf five, Cross tabulation for the participants' learning strategy and background knowledge, it can be seen clearly thar metacognitive was in the first place. To answer the second research question, Pearson product moment correlation coefficient was conducted to investigate the relationship amongs strategy use, demografic factors such as age, gender, major and background knowledge. The results are summarized in Table 6 .

Table 6. Pearson product moment correlation coefficient

\section{Correlations}

$$
\text { Strategy Gender } \begin{gathered}
\text { Background } \\
\text { Knowledge Age Major }
\end{gathered}
$$




\begin{tabular}{|c|c|c|c|c|c|c|}
\hline \multirow[t]{3}{*}{ Strategy } & $\begin{array}{l}\text { Pearson } \\
\text { Correlation }\end{array}$ & 1 &, $310^{* *}$ & ,039 & ,016 &,- 040 \\
\hline & Sig. (2-tailed) & & ,002 & ,708 & 879 & ,701 \\
\hline & $\mathrm{N}$ & 95 & 95 & 95 & 95 & 95 \\
\hline \multirow[t]{3}{*}{ Gender } & $\begin{array}{l}\text { Pearson } \\
\text { Correlation }\end{array}$ &, $310^{* *}$ & 1 &,$- 203^{*}$ &,- 124 & ,081 \\
\hline & Sig. (2-tailed) & ,002 & & ,048 & ,231 & ,434 \\
\hline & $\mathrm{N}$ & 95 & 95 & 95 & 95 & 95 \\
\hline \multirow[t]{3}{*}{$\begin{array}{l}\text { Background of } \\
\text { knowledge }\end{array}$} & $\begin{array}{l}\text { Pearson } \\
\text { Correlation }\end{array}$ & 039 &,$- 203^{*}$ & 1 & ,047 & ,012 \\
\hline & Sig. (2-tailed) & ,708 & ,048 & & 650 & ,907 \\
\hline & $\mathrm{N}$ & 95 & 95 & 95 & 95 & 95 \\
\hline \multirow[t]{3}{*}{ Age } & $\begin{array}{l}\text { Pearson } \\
\text { Correlation }\end{array}$ & ,016 &,- 124 & ,047 & 1 &,- 024 \\
\hline & Sig. (2-tailed) & 879 & ,231 & 650 & & ,815 \\
\hline & $\mathrm{N}$ & 95 & 95 & 95 & 95 & 95 \\
\hline \multirow[t]{3}{*}{ Major } & $\begin{array}{l}\text { Pearson } \\
\text { Correlation }\end{array}$ &,- 040 & ,081 & ,012 &,- 024 & 1 \\
\hline & Sig. (2-tailed) & ,701 & ,434 & ,907 & ,815 & \\
\hline & $\mathrm{N}$ & 95 & 95 & 95 & 95 & 95 \\
\hline
\end{tabular}

**. Correlation is significant at the 0.01 level (2-tailed).

*. Correlation is significant at the 0.05 level (2-tailed).

As indicated in Table 6, gender were the only demografic factors that were significantly correlated with the learners' learning strategy. The other factors significantly were not correlated amongs learning strategy use and demografic factors such as age, major and background knowledge. The relationship between learners' learning strategy and gender was found to be positively significant .002 (sig < .005), learning strategy use associated with gender were significantly correlated. Furthermore, specificly indicates that except compensasi all the strategy has corelation with gender.

\section{Discussions.}

The analysis was using correlate bivariate. In researching gender differences in the use of language learning strategies, for instance, analysis of variances has been used to determine whether, on average, females used specific categories of strategies significantly more often than males (e.g., Oxford \& Nyikos, 1989). Significant code variables to the latent factors indicated (a) significant gender differences, (b) significant differences among the four academic majors, and (c) significant interaction effect between gender, in the mean amount of the latent factors. The same statistical procedures were employed to analyze the effect of gender in all three sets of latent factors. Gender differences were identified as the female students (a) having stronger orientation toward social and financial benefits, and competition, and having greater amount of academic self-efficacy and intrinsic motivation, (b) having stronger beliefs about their language ability and valuing more the importance of language and strategy use, and (c) using more frequently self-directed practicing strategies. The male students, in contrast, valued more the importance of grammar and translation.

These results were consistent with gender differences discussed in the studies reviewed in introduction. Some studies found no significant gender differences in overall strategy use or the use of specific type strategies (e.g., Osanai, 2001; Yin, 2004), other studies reported that the female students used specific types of strategies significantly more often than males. This lends support to the hypothesis that females, compared with males, might have a stronger social orientation and thus might display a greater need for social approval (Oxford 
\& Nyikos, 1989; Oxford, Nyikos, \& Ehrman; 1988; Wen \& Johnson, 1997). Female students were also reported to value more the importance of self-management (Wen \& Johnson, 1997). Gender differences on the three sets of factors found in this study were very similar: females, compared with males, were found to value more the social and financial benefits of learning English, and the importance of language and strategy use. Relative to males, females reported greater academic self-efficacy, and were more orientated toward competition. Females also reported using self-directed practicing strategies significantly more often than males. Significant gender differences found on those constructs strengthened gender profiles reported in those studies, which lends support to the hypothesis that females are be more socially oriented and need more social approval than males.

A potential challenge, therefore, is for language teachers to tailor strategy instruction to the needs of individual learners. This challenge becomes especially real in the Indonesia EFL context given that language teachers often times need to meet the existing challenge of teaching large-size classes. Designing and delivering strategy-based language instruction to meet the needs of individual learners thus poses as an add-on challenge for language educators in Indonesia. Well-designed learning strategy instruction is based on a thorough understanding of learners' current strategy use (e.g., Chamot, 2004, 2005; Oxford, 1990, 1996a, 1996b,2001, 2002, forthcoming).

\section{CONCLUSION}

Gender is the only demographic factor that is significantly correlated with student learning strategies. Other factors are significantly not correlated between the use of learning strategies and demographic factors such as age, size and background of knowledge. The relationship between student learning strategies and gender was found to be significantly positive 0.002 ( $\mathrm{sig}<.005$ ), the use of learning strategies related to gender was significantly correlated. Furthermore, specifically shows that unless compensating for all strategies has a relationship with gender. Furthermore, there are significant differences in the use of learning strategies according to sex that support women. Especially in the attention strategy used, the value of the effect is at an important level. These results have parallels with the results of other studies (Dreyer \& Oxford, 1996; Lee \& Oxford, 2008), showing that women pay more attention to and use learning strategies more than men.

An important strategy for teachers to find out how their students can learn. strategies show teachers how they can help their students learn individually. Learning strategies must be considered for the learning process and the teaching process, because learning strategies vary according to students' learning styles (Ehrman \& Oxford, 1989; Nian-nian, 2012). For this reason, it can be said that instead of using only one method or strategy in the teaching and learning process, various types of learning strategies and methods must be used. According to Oxford (1999), students' learning styles and learning strategies within the scope of certain teaching methods can determine their learning abilities and their desire to learn. Thus, the results of this study highlight the strengths and weaknesses of student selfdetermination. Students' awareness of their learning strategies, and begin to use learning strategies that they did not use before can support their learning process (Shi, 2011). Learning strategies that they did not use before can support their learning process (Shi, 2011). In this context, future teachers must increase their self-awareness of the style of how to use student learning strategies according to their learning strategies. In this way, it will be easier to organize the learning environment according to the learning strategy and to help students use individual learning strategies. To understand learning strategies, it can be useful to investigate which learning strategies students use when learning with different learning materials, and to determine whether this can affect academic success. Furthermore, learning strategies were 
investigated with different variables in a wider sample. Cultural differences in learning styles and learning strategies can be investigated.

Finally, in this study gender is a strong influence in the use of student strategies. Subsequent research is expected to not only demographically examine the factors but more broadly namely motivation, IQ, attitude and learning outcomes.

\section{REFERENCES}

Abadogan, C. (2000). Ögretim stili odakli ders tasarimi gelistirme. Milli Egitim, 147, 61-63.

Chickering, A. W. (2006). Every student can learn-If.... About Campus, 11(2), 9-15.

Cohen, A. D. 1990. Language Learning: Insights Jor Learners, Teachers, and Researchers. NewYork: Newbury House.

Deryakulu, D. (2004). Üniversite ögrencilerinin ögrenme ve ders çalisma stratejileri ile epistemolojik inançlari arasindaki iliski. Kuram ve Uygulamada Egitim Yönetimi, 38, 230249.

Dreyer, C., \& Oxford, R. L. (1996). Learning strategies and other predictors of ESL proficiency among Afrikaans speakers in South Africa. In: R. L. Oxford (Ed.), Language Learning strategies around the world: Cross-cultural perspectives (Tech. Rep. No. 13, pp. 61-74).Honolulu, HI: University of Hawaii Press.

Ehrman, M., \& Oxford, R. (1990). Adult language learning styles and strategies in an intensive training setting. The modern language journal, 74(3), 311 -327.

Felder, R. M., \& Brent, R. (2005). Understanding student differences. Journal of EngineeringEducation, 94(1), 57-72.

Gagne, R. M. (1974). Essentials of Learning for Instruction. USA: The Dryden Press.

Lee, K. R., \& Oxford, R. L. (2008). Understanding EFL learner's strategy use and strategyawareness. Asian EFL Journal, 10(11), 7-32.

Naiman, N., Fröhlich, M., Stern, H., \& Todesco, A. (1978). The good language learner. Research in Education Series. No. 7. Toronto: Ontario Institute for Studies in Education.

Nian-nian, W. (2012). Relationship between English learning strategies and learning style preferences: An empirical study. Sino-US English Teaching, 9(9), 1502-1509.

O'Malley,J. M. dan Chamot, A. U. 1990.Learning Strategies in Second LanguageAcquisition.NewYork:Cambridge University Press.

Oxford, R. L. (1990). Language learning strategies: What every teacher should know. New York: Newbury House.

Oxford, R. L. (1999). Relationships between learning strategy use and language proficiency in the context of learner autonomy and self-regulation. In L. Bobb (Ed.), Learner Autonomy as a Central Concept of Foreign Language Learning, Special Issue of Revista Canaria de Estudios Ingleses, 38, 109-126.

Oxford, R.L. (1990a). Language learning strategies and beyond: A look at strategies in the context of styles. In S.S. Magnan (Ed.), "Shifting the instructional focus to the learner," 35-55. Middlebury, VT: Northeast Conference on the Teaching of Foreign Languages.

Phillips, V. 1991. "A Look at Leamer Strategy Use and ESL Proficiency". The CATESOLJournal. November 1991.57-67. 